\title{
Effect of feeding maize silage supplemented with concentrate and legume hay on growth in Nellore ram lambs
}

\author{
Venkateswarlu Malisetty ${ }^{1}$, Ramana Reddy Yerradoddi ${ }^{1}$, Nagalakshmi Devanaboina ${ }^{1}$, \\ Mahender Mallam², Hari Krishna Cherala ${ }^{2}$, Rajasekhara Reddy Admal ${ }^{3}$ and Gnana Prakash Manthani ${ }^{4}$ \\ College of Veterinary Science, \\ Sri Venkateswara Veterinary University, Rajendranagar, Hyderabad-500030, India. \\ 1. Department of Animal Nutrition; 2.Department of Livestock Production and Management: \\ 3. Department of Poultry Science; 4. Department of Animal Genetics and Breeding \\ Corresponding author: Venkateswarlu Malisetty, email: malisettyv46@gmail.com \\ Received: 24-08-2012, Accepted: 28-09-2012, Published online: 19-01-2013
}

How to cite this article: Malisetty V, Yerradoddi RR, Devanaboina N, Mallam M, Cherala HK, Admal RR and Manthani GP (2013) Effect of feeding maize silage supplemented with concentrate and legume hay on growth in Nellore ram lambs, Vet. World 6(4): 209-213, doi: 10.5455/vetworld.2013.209-213

\begin{abstract}
Aim: The main intension of this research work is to develop a feeding system for growing Nellore ram lambs by feeding maize silage based rations supplemented with concentrate and or legume hay at certain levels to investigate the growth rate.

Materials and Methods: Experimental animals (Nellore ram lambs) were purchased from local sandy and maize silage was prepared at village by using silos (9"L X 9"W X 8"D) and concentrate mixture was prepared at feed mill located at department by using locally available ingredients. Animals were housed in well ventilated sheds and were dewormed and vaccinated against diseases. Fortnightly body weights were taken by using spring balance and calculated the total weight gain and ADG. The experimental animals were divided into seven groups based on their body weight to contain six in each and were fed intensively for five months with sole maize silage (R-I), silage + concentrate at 0.5 per cent body weight (R-II), silage + concentrate at 1.0 per cent body weight (R-III), silage + concentrate at 1.5 per cent body weight (R-IV), silage + lucerne hay $(\mathrm{R}-\mathrm{V})$ and silage + GN haulms (R-VI) and sweet sorghum bagasse based complete diet (R-VII) to study the growth rate.
\end{abstract}

Results: Significantly $(P<0.01)$ increase in ADG was observed in ram lambs fed R-IV ration was 16.58, 20.49, 24.10, 29.74, 38.28 and 62.01 per cent, respectively in comparison to those fed R-VII, R-V, R-III, R-VI, R-II and R-I rations. Almost similar ADG was noticed in lambs fed R-III, R-V and R-VII rations and the supplementation of concentrate at $0.5 \%, 1.0 \%$ and $1.5 \%$ of body weight plus maize silage ad lib has increased the growth/gain in ram lambs by $62.48,99.81$ and 163.25 per cent, respectively in comparison to sole silage feeding. Similarly, supplementation of lucerne hay and groundnut haulms with maize silage has increased the weight gain by 109.31 and 84.97 per cent, respectively in comparison to sole maize silage fed animals. Sole sweet sorghum bagasse (SSB) based complete ration (50:50) fed lambs (R-VII ration) showed the ADG almost similar to those animals fed lucerne hay plus maize silage $a d$ lib.

Conclusions: Based on the results of this study, it is concluded that, maize silage can be supplemented either with lucerne hay, groundnut haulms (to meet $25 \%$ of DM requirement) or concentrate mixture at $1.5 \%$ of body weight for obtaining optimum growth rate in Nellore ram lambs.

Key words: growth rate, legume hay, maize silage, Nellore ram lambs

\section{I ntroduction}

Maize (Zea mays) is the nutritious feed for small and large ruminants have high protein efficiency ratio (PER), relatively high digestible energy (DE) and total digestible nutrients and thus maize fodder can play an important role in supplying animal feed throughout the year if we cultivate them. [1]. Feeding of silage based rations is becoming popular among the farmers rearing sheep on commercial basis in India particularly in Andhra Pradesh and Karnataka. However, a feeding system based on silage needs to be developed for rearing of ram lambs on commercial basis since literature on silage feeding in ram lambs is limited. Silage, which is anaerobically fermented green fodder, is valued throughout the world as a source of animal feed during lean months (2). Maize is the third most important cereal crop of the world. It is used as food, feed and forage. Maize fodder can safely be fed at all stages of growth without any danger of oxalic acid, prussic acid as in case of sorghum or other fodders. Therefore, green maize fodder is referred as 'king of crops' suitable for good silage making [3]. Very limited numbers of sheep farmers are feeding their ruminants with silage in India. Farmers in Andhra Pradesh, India are showing interest in preparation and feeding of silage based rations to their ruminant animals particularly small ruminants like growing sheep to obtain optimum body weight.

In view of the farmers' awareness on feeding of silage to small ruminants for meat production, an attempt was made to feed the maize silage by supplementing concentrate and legume hay at certain levels to study the growth rate in Nellore ram lambs.

\section{Materials and Methods}

This on-farm experiment was carried out with maize silage at Indugula village in Tipparthy mandal of Nalgonda district, Andhra Pradesh, India. The main 
source of irrigation for food crops or forage crops here is by rains, bore wells and small tanks. Average rainfall was $50-60 \mathrm{~mm}$ per annum and occurs chiefly due to southwest monsoons every year from June to September. Soil is of mostly red (chalka) type. The experimental animals had faced the maximum environmental temperature of about $44^{\circ} \mathrm{C}$ in the month of May and the minimum was about $23^{\circ} \mathrm{C}$ during the entire five months experimental period.

Ethical approval: The experiment was approved by Institutional Animal Ethics Committee.

Silage making: The farmer who reared the experimental ram lambs is having 20 acres of land with bore well as well as sprinkler irrigation facility. The farmer was already rearing 100 sheep which were being maintained by grazing on open fields. The land used to grow the maize crop for silage making was ploughed thoroughly for 3 times with a tractor and about 2 tons of farm yard manure per acre was applied as a basal fertilizer. Nitrogen, phosphorus and potassium fertilizers were purchased from local market and applied at the rate of 60,24 and $10 \mathrm{~kg}$ per acre, respectively. A 36V92 variety of maize seed was selected and purchased from Pioneer seeds Pvt. Ltd., Hyderabad for growing the maize fodder for silage making. Physical or chemical treatment of seed was not done prior to sowing.

Seed rate was $8.5 \mathrm{~kg} / \mathrm{acre}$. While sowing with hand, the distance maintained between the rows was 1.5 feet and between the seeds was 7 inches. About $5 \mathrm{~g}$ of urea fertilizer was placed along with a maize seed while sowing. Corbofuron granules were placed in the rows after sowing to prevent the infestation by insects after germination. Maize seeds were sowed in the winter season $\left(15^{\text {th }}\right.$ November, 2009). Irrigation was done by sprinklers for first 60 days followed by bore well once in 15 days till harvest. Herbicide (Atrazin @ 1.5 litres in 200 litres of water per acre) was used on the next day of sowing to prevent the growth of weeds in the field. Monocrotophos an insecticide was sprayed over the growing fodder on $40^{\text {th }}$ day. Booster dose of urea was applied on $15^{\text {th }}, 30^{\text {th }}$ and $40^{\text {th }}$ day.

Maize fodder was harvested on $87^{\text {th }}$ day after sowing when the cob containing one fourth to half milky grains. Harvested green fodder was allowed to wilt in the field for 4-6 $\mathrm{h}$ to reduce the moisture content to around 65 per cent.

Two silo pits were constructed/digged near the experimental animal shed with the dimensions of 9' $\mathrm{L} x$ $9^{\prime} \mathrm{W}$ x 8' $\mathrm{D}$ so as to accommodate about 10 tons of silage in each pit. All the inside walls and bottom of silo was cemented to prevent seepage of ground water if any. All the sides of the silos were covered with HDPE plastic cover before filling the pit with chopped maize fodder.

Harvested and wilted green fodder was brought to the site of silage pit from the field by using a tractor. The 10 HP motor capacity chop cutter was arranged at one edge of silo in order to allow the chopped green fodder directly to fall into the pit. About 5-6 whole maize plants were kept in the chop cutter at a time so as to cut the fodder to a size of $1 / 2$ to $3 / 4$ inches.

Sugarcane molasses, urea (fertilizer grade) and common salt were added at $1,0.5$ and 0.5 per cent, respectively while making the silage. They were mixed in water (50 litres/ton of fodder) in a plastic drum thoroughly with a long stick and were sprinkled uniformly all over the maize fodder while chopping them through a chop cutter.

Chopped green maize fodder was trampled (compacted) with wooden planks by two persons for every one foot level in the pit. Great care was taken while trampling chopped silage fodder to prevent trapping of air in the pit in order to maintain strict anaerobic condition in the silo.

After filling the chopped fodder to about 2 feet's above the ground level it was tightly covered with HDPE plastic covers and heavy weight sand bags were placed over the pit to prevent entry of air and water into silo. Pit slope to one side was maintained to drain water quickly if rain occurs. Silo was opened on 39th day for the feeding of experimental ram lambs.

Preparation of concentrate mixture: Concentrate feed ingredients were procured from the local Hyderabad market. Concentrate mixture with 17\% CP and 70\% TDN was prepared in the feed mill located at Department of Animal Nutrition, College of Veterinary Science, Rajendranagar, Hyderabad, India and transported to Indugula village for feeding of ram lambs.

Lucerne (Medicago sativa) crop was grown at the farmer's fields at Indugula village and was harvested at $50-60 \%$ flowering stage. Harvested green lucerne fodder was dried under shade for 3-4 days in order to contain $12-14 \%$ moisture. While drying, the fodder was turned upside down three times a day to prevent growth of fungus and to hasten the process of drying. Prepared hay was filled in the gunny bags and stored for feeding of experimental ram lambs. Groundnut (Arachis hypogea) haulms were purchased (INR. 3.00 per $\mathrm{kg}$ ) from another farmer in Indugula village for the feeding of experimental ram lambs. Sweet sorghum bagasse (SSB) was procured from ICRISAT, Patancheru, Hyderabad to prepare complete ration. Concentrate ingredients were purchased from local market in Hyderabad. Complete ration with 50 per cent level SSB was processed into mash according to the formula using hammer mill through $8 \mathrm{~mm}$ sieve at the feed mill of Department of Animal Nutrition, College of Veterinary science, Rajendranagar, Hyderabad and was transported to Indugula village to feed the experimental ram lambs.

Selection and grouping of ram lambs: Forty nine 3-4 months old growing Nellore ram lambs with an average body weight of $14.26 \pm 0.24 \mathrm{~kg}$ were purchased from Karimnagar, Karimnagar district of Andhra Pradesh and were randomly distributed into seven groups of seven animals each. The average body weight $(\mathrm{kg})$ of 
ram lambs in seven treatments was $14.33 \pm 0.85\left(\mathrm{~T}_{1}\right)$, $14.33 \pm 0.47\left(\mathrm{~T}_{2}\right), 14.20 \pm 0.56\left(\mathrm{~T}_{3}\right), 14.23 \pm 0.87\left(\mathrm{~T}_{4}\right)$, $14.30 \pm 0.46\left(\mathrm{~T}_{5}\right), 14.32 \pm 0.62\left(\mathrm{~T}_{6}\right)$ and $14.10 \pm 0.86\left(\mathrm{~T}_{7}\right)$, respectively.

Experimental silage rations: Seven experimental groups were fed with respective rations as mentioned below for a period of five months.

The first group $\left(T_{1}\right)$ of growing Nellore ram lambs were fed sole maize silage at ad libitum.

The second group $\left(\mathrm{T}_{2}\right)$ animals were fed concentrate mixture @ 0.5 per cent of body weight + maize silage ad libitum.

The third group $\left(\mathrm{T}_{3}\right)$ animals were fed concentrate mixture @1.0 per cent of body weight + maize silage ad libitum.

The fourth group $\left(\mathrm{T}_{4}\right)$ animals were fed concentrate mixture@1.5 per cent of body weight + maize silage ad libitum.

The fifth group $\left(\mathrm{T}_{5}\right)$ of ram lambs was fed lucerne hay to meet 25 per cent of dry matter requirement and maize silage ad libitum.

The sixth group $\left(\mathrm{T}_{6}\right)$ of ram lambs was fed groundnut haulms (straw) to meet 25 per cent of dry matter requirement and maize silage ad libitum.

The seventh group $\left(\mathrm{T}_{7}\right)$ ram lambs were fed solely on SSB based complete ration (50:50).

Housing, feeding, watering and management : The ram lambs were housed according to groups in well ventilated, clean pens (24'LX10'W) with an open area (24'LX10'W) for movement during the day time. Ordinary flooring (soil) was maintained in the pens. All the experimental ram lambs were offered their respective feeds at 9.00 and $15.00 \mathrm{~h}$ by weighing on an electronic digital balance and residue if any was weighed after $24 \mathrm{~h}$. The growth trial was conducted for a period of 150 days. All the experimental animals were offered clean, fresh drinking water round the clock. Hygienic surroundings were maintained throughout the experimental period. All the animals were treated for external and internal parasites with Ivermectin and Fenbendazole drugs, respectively, in the beginning as well as after three months of experimental period. Animals were vaccinated against PPR disease after seven days of first deworming.

Recording of live weight: The animals were weighed fortnightly using a spring balance before offering the feed and water in the morning. Weights were recorded on two consecutive days and the mean was taken to represent the body weight. Average daily gain (ADG) was calculated by using the formula.

$$
\text { ADG }(g)=\text { Final weight }(g)-\text { Initial weight }(g)
$$

\section{Results and Discussion}

The fortnightly body weights (Table-1) were ranged from $14.65 \pm 0.85$ to $19.18 \pm 1.05 ; 14.70 \pm 0.49$ to $22.21 \pm 0.57 ; 14.62 \pm 1.06$ to $23.89 \pm 0.66 ; 14.75 \pm 0.86$ to $27.00 \pm 1.08 ; 14.88 \pm 0.51$ to $24.45 \pm 0.48 ; 14.85 \pm 0.65$ to $23.28 \pm 0.75$ and $14.63 \pm 0.86$ to $24.75 \pm 1.08$, respectively in ram lambs fed rations R-I, R-II, R-III, R-IV, R$\mathrm{V}, \mathrm{R}-\mathrm{VI}$ and R-VII from $1^{\text {st }}$ fortnight to $10^{\text {th }}$ fortnight. The values were non significantly different from $1^{\text {st }}$ fortnight to $5^{\text {th }}$ fortnight, significantly $(P<0.05)$ different during $6^{\text {th }}$ fortnight and more significantly $(P<0.01)$ different from $7^{\text {th }}$ to $10^{\text {th }}$ fortnight among the Nellore lambs fed different maize silage and SSB based rations. Fortnightly body weights $(\mathrm{kg})$ of Nellore ram lambs was linearly $(P<0.05)$ increased by $11.06-15.80$ to $28.77-40.77$ per cent from $7^{\text {th }}$ to $10^{\text {th }}$ fortnight in ram lambs supplemented with different supplements and SSB based ration. The variation in the fortnightly body weight changes may be due to variation in quantity and quality of supplements offered along with the maize silage. Fortnightly body weights obtained in lambs fed SSB based ration was comparable with maize silage supplemented with concentrate at $1.0 \%$ of body weight, groundnut haulms and lucerne hay each supplemented at $25 \%$ of DM requirement to maize silage fed ram lambs.

Average daily gain: The average daily gain (ADG) observed in the growing Nellore ram lambs fed rations R-I (sole silage), R-II (silage + concentrate mixture @ $0.5 \%$ body weight), R-III (silage + concentrate mixture @ $1.0 \%$ body weight), R-IV (silage + concentrate mixture @ 1.5\% body weight), R-V (silage + lucerne hay to meet $25 \%$ DM requirement), R-VI (silage + groundnut haulms to meet $25 \% \mathrm{DM}$ requirement) and R-VII (sweet sorghum bagasse based complete ration) were $32.33 \pm 1.79,52.53 \pm 2.78,64.60 \pm 0.96,85.11 \pm$ $3.78,67.67 \pm 1.15,59.80 \pm 1.59$ and $71.00 \pm 1.88 \mathrm{~g}$, respectively (Table-2).

Significant $(P<0.01)$ difference among experimental animals fed different maize silage and SSB based rations was observed. ADG was highest $(P<0.01)$ in lambs fed ration IV in comparison to other rations. No difference in ADG between R-V and R-VII rations.

Increase in ADG in R-IV ration was 16.58 per cent with R-VII ration, 20.49 per cent with R-V ration, 24.10 per cent with R-III ration, 29.74 per cent with RVI ration, 38.28 per cent with R-II ration and 62.01 per cent with R-I ration (sole silage) in ram lambs. Almost similar ADG was noticed between the lambs fed R-III and $\mathrm{R}-\mathrm{V}$ rations, $\mathrm{R}-\mathrm{III}$ and $\mathrm{R}-\mathrm{VI}$ rations as well as $\mathrm{R}-\mathrm{V}$ and R-VII rations.

Supplementation of concentrate at $0.5 \%, 1.0 \%$ and $1.5 \%$ of body weight plus maize silage $a d$ lib has increased the growth/gain in ram lambs at the rate of $62.48,99.81$ and 163.25 percent, respectively in comparison to sole silage feeding. Similarly, supplementation of lucerne hay and groundnut haulms (to meet 25\% DM requirement) with maize silage has also increased the weight gain at 109.31 and 84.97 per cent, respectively in comparison to sole maize silage fed animals. 
Table-1. Fortnightly body weights $(\mathrm{kg})$ of Nellore ram lambs fed maize silage and SSB based rations

\begin{tabular}{|c|c|c|c|c|c|c|c|c|c|c|c|}
\hline Ration & Initial weight & 1 & 2 & 3 & 4 & 5 & $\begin{array}{c}\text { Fortnight } \\
6 *\end{array}$ & 7** & $8^{* * *}$ & 9** & Final weight** \\
\hline R-I & $14.33 \pm 0.85$ & $14.65 \pm 0.85$ & $15.05 \pm 1.07$ & $15.53 \pm 0.83$ & $15.98 \pm 0.94$ & $16.45 \pm 1.04$ & $16.93^{\mathrm{a}} \pm 0.84$ & $17.45^{\mathrm{a}} \pm 0.87$ & $17.92^{\mathrm{a}} \pm 0.88$ & $18.53^{\mathrm{a}} \pm 0.96$ & $19.18^{a} \pm 1.05$ \\
\hline R-II & $14.33 \pm 0.47$ & $14.70 \pm 0.49$ & $15.33 \pm 0.50$ & $16.03 \pm 0.52$ & $16.92 \pm 0.60$ & $17.68 \pm 0.47$ & $18.57^{\mathrm{ab}} \pm 0.50$ & $19.38^{\mathrm{ab}} \pm 0.54$ & $20.32^{\circ} \pm 0.51$ & $21.37^{\mathrm{b}} \pm 0.55$ & $22.21^{b} \pm 0.57$ \\
\hline R-III & $14.20 \pm 0.56$ & $14.62 \pm 1.06$ & $15.27 \pm 0.57$ & $16.12 \pm 0.61$ & $17.15 \pm 0.60$ & $18.13 \pm 0.57$ & $19.25^{b c} \pm 0.58$ & $20.33^{b c} \pm 0.54$ & $21.50^{b c} \pm 0.62$ & $22.80^{\mathrm{bc}} \pm 0.65$ & $23.89^{\mathrm{bc}} \pm 0.66$ \\
\hline R-IV & $14.23 \pm 0.87$ & $14.75 \pm 0.86$ & $15.68 \pm 0.89$ & $16.90 \pm 0.86$ & $18.08 \pm 0.87$ & $19.43 \pm 0.77$ & $20.95^{\circ} \pm 0.86$ & $22.47^{\circ} \pm 0.81$ & $24.10^{\mathrm{d}} \pm 0.92$ & $25.67^{\mathrm{d}} \pm 0.98$ & $27.00^{\mathrm{d}} \pm 1.08$ \\
\hline$R-V$ & $14.30 \pm 0.46$ & $14.88 \pm 0.51$ & $15.75 \pm 0.50$ & $16.87 \pm 0.51$ & $18.08 \pm 0.59$ & $16.27 \pm 0.60$ & $20.22^{\mathrm{bc}} \pm 0.65$ & $21.27^{\mathrm{bc}} \pm 0.68$ & $22.25^{\text {bod }} \pm 0.59$ & $23.53^{\text {bed }} \pm 0.51$ & $24.45^{\mathrm{bc}} \pm 0.48$ \\
\hline $\mathrm{R}-\mathrm{VI}$ & $14.32 \pm 0.62$ & $14.85 \pm 0.65$ & $15.58 \pm 0.68$ & $16.67 \pm 0.68$ & $17.70 \pm 0.68$ & $18.73 \pm 0.67$ & $19.85^{\mathrm{bc}} \pm 0.62$ & $21.10^{\mathrm{bc}} \pm 0.68$ & $21.73^{\mathrm{bc}} \pm 0.69$ & $22.55^{\mathrm{bc}} \pm 0.68$ & $23.28^{\mathrm{bc}} \pm 0.75$ \\
\hline R-VII & $14.10 \pm 0.86$ & $14.63 \pm 0.86$ & $15.52 \pm 0.87$ & $16.78 \pm 0.86$ & $17.87 \pm 0.89$ & $19.03 \pm 0.96$ & $20.32^{b c} \pm 1.02$ & $21.55^{\mathrm{bc}} \pm 1.13$ & $22.60^{\mathrm{cd}} \pm 1.13$ & $23.82^{\mathrm{cd}} \pm 1.13$ & $24.75^{\circ \mathrm{co}} \pm 1.08$ \\
\hline
\end{tabular}

Each value is the average of six observations; $a, b, c, d, e, f$ values bearing different superscripts in a row differ significantly( $P<0.01)$

Table-2. Effect of feeding maize silage based rations on growth rate, feed efficiency and cost economics in Nellore ram lambs

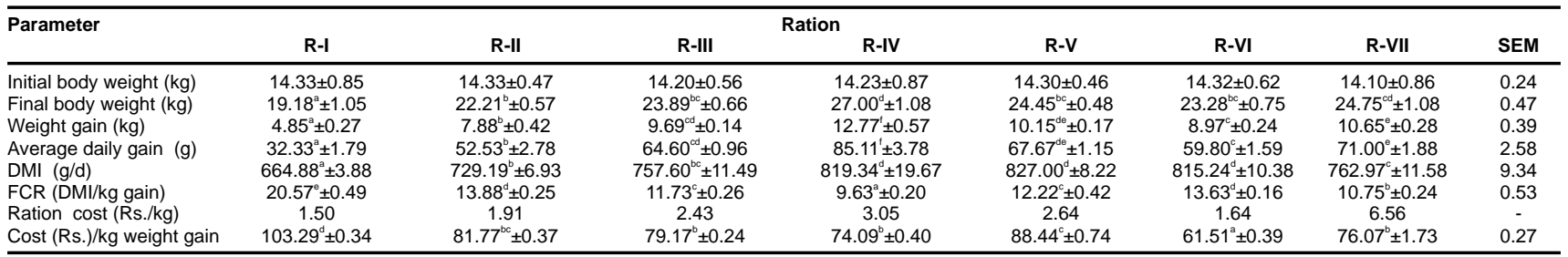

Each value is the average of six observations; $a, b, c, d, e, f$ values bearing different superscripts in a row differ significantly $(P<0.01)$

Supplementation of grass silage with rape seed meal or barley resulted in ADG of $1124 \mathrm{~g}$ and $1070 \mathrm{~g}$ in comparison to $1012 \mathrm{~g}$ in un supplemented Ayrshire cattle [4]. Green grass $a d l i b$ and palm kernel cake at levels of $0,0.45,0.90,1.35$ and 1.80 per cent of their live weight and found significant increase in weight gain in growing lambs [5]. Supplementation of concentrate with maize silage in the present study increased $(P<0.01)$ the daily gain as the level of concentrate increased in the diet.

Supplementation of forage based ration with 75$100 \mathrm{~g}$ each of maize and GNC increased the ADG in weaner lambs [6]. Supplementation of concentrate (GNC) to maize silage increased the ADG by $178 \mathrm{~g}$ in comparison to sole maize silage feeding [7]. British Friesian steers fed grass silage on supplementation with energy or energy-protein supplement showed live weight gain of 0.69 to $0.8 \mathrm{~kg}$ [8]. Goats fed chloris gayana green fodder with supplemented $200 \mathrm{~g}$ of concentrate found increased dry matter intake and increased growth rate [9].

The ADG and FCR found in the present study results was in consistent with the results of [10]. They conducted a study in sipli lambs fed maize silage alone and maize silage plus concentrate supplementation at $50 \%$ level.

Almost similar findings in Sikkim local male kids fed mixed jungle grass and concentrate at $0.5,1.0$ and 1.5 per cent of body weight [11]. Supplementation of concentrate improved the weight gain in growing ruminants was studied [12] in growing male calves and [13] in beef cattle. Supplementation of basal diet with legume fodders has shown significant increase in growth rate in goats and sheep [14-16].

\section{Conclusion}

It is concluded that, maize silage can be supplemented either with lucerne hay, groundnut haulms (to meet $25 \%$ of $\mathrm{DM}$ requirement) or concentrate at $1.5 \%$ of body weight depending on the availability for optimum growth rate and feed efficiency in growing Nellore ram lambs.

\section{Author's contribution}

VM, RRY, ND and MM implemented the study design. VM and GPM recorded the data and analyzed. VM drafted the manuscript. VM, RRY, ND, MM, GPM and RRA revised the manuscript. All authors read and approved the final manuscript.

\section{Acknowledgements}

The authors are thankful to the authorities of National Agricultural Innovation Project (NAIP), Indian Council of Agricultural Research (ICAR), New Delhi, India for providing financial assistance to carry out this investigation. Appreciation is expressed to farmers Sri. A. Venkat Reddy \& Co. at Indugula village in Nalgonda district, India for their cooperation and support for smooth conduct of this study.

\section{Competing interests}

Authors declare that they have no competing interest.

\section{References}

1. Desai, S.N. and Deore, D. D. (1984) Effects of detectrate, spacing and nitrogen fertilizer on growth and forage production, J. of Maharashtra Agril. Uni., India, 8:109-111.

2. Ragothaman, Venkataramanan., Chirukandoth, Sreekumar., Rishipal, Anilkumar., Selvaraj, P., Nainar, M. Vidhya. and Iyue, Mathagowder. (2010) Effect of jaggery on the quality and intake levels of maize silage. Trop. Ani. Health and Prod. 42 (5):1027-1029.

3. Muhammad, D., Hussain, A. and Bhati, M. B. (1990) Location differences in forage yield and quality of maize cultivars. Pakistan J. of Sci. and Res. 33:454-456.

4. Huhtanen, P., Poutianinen, E. and Mikkola, T. (1985) The effect of supplementation of grass silage with rape seed meal or Gasol - treated barley on the performance of growing cattle. J. of Agril. Sci. in Finland. 57:75-84.

5. Mustaffa Babjee, A. (1988) The use of palm kernel cake as animal feed .Part II. Asian Livestock. 8:29-33.

6. Pratap Reddy, V., Rama Prasad, J., Krishna N. and Anjaneya Prasad, D. (1989). Effect of supplementation of energy and protein to forage based basal ration in Nellore weaner lambs. Indian J. of Anim. Nutri. 6:302-306.

7. Chauhan, T. R. and Brar, G. S. (1989) Effect of replacing conventional concentrate mixture with deoiled groundnut cake on the nutrient utilization in maize silage based rations of buffalo calves. Indian J. of Anim. Sci. 59:893-896. 
8. Steen, R.W.J. (1989) A comparison of soybean, sunflower and fish meal as protein supplements for yearling cattle offered grass silage based diets. Anim. Prod. 48:81-89.

9. Mtenga, L.A. and Kitlay, A. J. (1990) Growth performance and carcass characteristics of Tanzanian goats fed Chloris gayana hay with different levels of protein supplement. Small Rumin. Res. 3:9-18.

10. Sohail, H. K., Muhammad, A. S., Maher, N. and Muhammad, S. (2010) Nutrients intake, digestibility, nitrogen balance and growth performance of sheep fed different silages with or without concentrate. Trop. Anim. Health and Prod. DOI 10.1007/s11250-010-97651.

11. Das, A. (2010) Effect of different levels of concentrate supplementation on performance of Sikkim local kids fed mixed jungle grass based diet. Anim. Nutri. and Feed Tech. 10:87-97.

12. Begum, N., Khan, M. J. and Islam, K. M. S. (2000) Feeding rations containing roadside grass, maize silage or water hyacinth in bull calves. Pakistan J. of Biological Sci. 3(10): 1730-1732.

13. Pereira, D. H., Pereira, O. G., Valadares, F. S. C., Garcia, R., Oliveira, A. P., Martins, F. H. and Viana, V. (2006) Effects of feeding sorghum silage (Sorghum bicolor (L.) moench) with different concentrate levels on intake, nutrient digestibility, and production of beef cattle. Brazilian J. of Anim. Sci. 35 (1):25-29.

14. Upadhyay, V. S. (1987) Response of Barbari goats to supplemental feeding of Leucaena Leucocephala (Subabul). Indian J. of Anim. Prod. and Manag. 3:92-95.

15. Mtenga, L. A. and Shoo, R. A. (1990) Growth rate, feed intake and feed utilization of small East African goats supplemented with Leucaena leucocephala. Small rumin. Res. 3:19-18.

16. Adejumo, J. O. and Ademoson, A. A. (1991). Utilization of Leucaena as supplement for growing Dwarf sheep and goats in the humid zone of West Africa. Small Rumin. Res. 5:75-82.

$* * * * * * * *$ 